\title{
Food Resources of Siberia and the Region and the Prospects for a Sustained Work in Global Markets
}

\author{
Vasily V. Kuimov and Eva V. Shcherbenko* \\ Siberian Federal University \\ 79 Svobodny, Krasnoyarsk, 660041, Russia
}

Received 18.05.2017, received in revised form 05.11.2017, accepted 08.11.2017

\begin{abstract}
The analysis of the resources of Siberia and the region for the production of food for the implementation of the UN Agenda for sustainable development for the period up to 2030. Shows significant advantages Siberia on the background of significant climate change in others, including highly populated areas of the earth and especially the growing water shortage and water resources as the basis for the production of food resources in these areas. Despite new technologies and economical use of water the value of land with high water availability and climatic conditions for the development of food including Siberia, New Zealand, the separate territories of the tropical zone, acquires a strategic significance for mankind. Shown substantial unused resources in the Siberian regions and Krasnoyarsk territory in particular, do not use more than 5000 million hectares of previously arable land resources for livestock and wild plants, there is considerable scope for the formation of modern cooperative-network interaction for the rapid growth of the food market and export to global markets.
\end{abstract}

Keywords: sustainable development, food, Siberia, resources for food exports.

DOI: 10.17516/1997-1370-0168.

Research area: economics.

\section{Introduction}

The FAO report "Global Future of Food Security "is Open to Question"” states that, despite significant progress, the potential of humanity to feed themselves is under threat due to increasing pressure on natural resources and rising inequality (Mirovoe budushchee..., 2017).

\section{Theoretical framework}

For many decades the problems of food security and fighting hunger are constant issues of the UN and its organizations. The programme of the millennium development goals, adopted in 2000 , states the reduction of hunger and food development as the first development goal out of eight ones. Its successful implementation in many countries has led to a significant reduction of the number of hungry (167 million) and undernourished (795 million) people on the planet. 193 member states of the UN adopted a new "Agenda for Sustainable Development till $2030 "$ at the anniversary session of the United

C) Siberian Federal University. All rights reserved

* Corresponding author E-mail address: kuimov1945@mail.ru 
Nations in September 2015. 7 goals out of 17 new ones set for the following 15 years are related to food and contain new areas, the areas being "to achieve food security and improve nutrition" (goal 2), "to ensure healthy lifestyle" (goal 3), "to ensure sustainable consumption and production patterns" (goal 12), i.e. not only to reduce hunger but achieve high-quality healthy nutrition (Preobrazovanie nashego mira..., 2015).

All these tasks become even more actual since by 2050 there will be about 10 billion inhabitants on the planet. Given that their level of welfare will increase, this will require actual increase of food up to 50 per cent to the current level. Yet, the conditions of its production both in plant growing and livestock farming are significantly impaired due to the fact that "almost half of the forests that once covered the Earth are already destroyed. Groundwater is rapidly running out. Biodiversity is impetuously disappearing". According to the report "The Future of Food and Agriculture: Trends and Challenges", "food production development and economic growth often come at a high cost to the environment". As a result, if these trends persist, the planet might fail to cope. This is what José Graziano da Silva, director general of FAO, warned about in his introduction to the report (Mirovoe budushchee..., 2017).

\section{Problem Statement}

In these conditions the following trends of food development on the planet become central: better use of existing resources of fertile land, water, new technologies in agriculture and establishment of industrial enterprises of basic elements of food - protein, fat, etc. It is known that as per climate and availability of water these are New Zealand, Australia, forests of the tropical area, Russia and Siberia, in particular, that will become the promising regions of new development of food.

\section{Discussion}

From these positions, it is worth while estimating the condition of food market of Siberia and the region and its resources that can have impact on the food situation in the world. Food production resources of Siberia, including organic products, are quite high. For successful farming the region has fertile lands, abundance of pure water, plenty of sun and rain. Only in the Siberian Federal District, uniting 12 regions of Russia, lands under cultivation currently cover more than 15000 thousand hectares, that is nearly 19 per cent of the total cultivated area of Russia. Good resource for the food production development is also peculiar for the regions of the Far Eastern Federal District with almost 2000 hectares of lands under cultivation. 52 per cent of soy beans of their total production in Russia are gathered here. There are also great opportunities for further animal husbandry development (Kuimov et al., 2015).

Siberia and the regions of the Far East produce almost half of the total harvest of buckwheat, approximately 40 per cent of oats, more than 15 per cent of wheat. Resources for meat and milk production are also great. Almost every fifth ton of pork and beef is produced here.

Considerable potentialities for expanding arable and agricultural lands are also important. In the period up to 1991 more than 20000 hectares were under cultivated lands. More than 5 thousand hectares were currently not used. They have fully recovered from previously used fertilizers and are a good basis for the production of ecologically clean products (Kuimov et al., 2015).

In the new globalized world Siberia is a significant resource from different perspectives: mineral resources availability and Siberia's natural resources, including the food production one.

As for food security, the most significant phenomena of the new world are: 
- rapid development of the most densely populated megaregions of the earth, China's commanding lead in the world development, China being the leading economically developed nation in the world, rapid development of India, Indonesia, Vietnam, Brazil and other countries;

- significant reductions in the resources of the traditional food production in a number of leading countries. The report of the Board of the U.S. intelligence services "Global Trends 2030: Review. Megatrends", published in 2014, forecasts that "the need for the resources will increase to a large extent due to global population growth. The solution of problems in the field of mass consumption products will be related to the level of other products consumption" (Global'nye tendentsii - 2030..., 2012).

The authors of the research argue that the process of development till 2030 will be implemented "in the conditions of a growing shortage of food, water, energy resources. As a result of the world population growth and middle class increase the need for food, water and energy will grow by approximately 35, 40 and $50 \%$, respectively. Climate change will worsen the prospects of these important resources availability in many regions of the world. (The main changes in precipitation will take place in the Near East and North Africa as well as in the west of Central Asia, in the south of Europe, Southern Africa and the Southwestern USA). It is a growing demand for water and food that becomes decisive against the background of the whole complex of changes in population and climate. Almost half of the world's population will live in the areas with acute water shortages. China and India will also face this problem" (Global'nye tendentsii - 2030..., 2012).

Against this background, Siberian territories with their huge resource of fresh water, agricultural and forest lands can be reasonably used for the development of Russia and for the benefit of other countries in the course of mutually beneficial cooperation. This standpoint should be taken into account by Russia and the countries facing the problems of food production development and freshwater availability. Together with the world community they must work out the programme of active development of food production in Siberia as well as supply of clean drinking water into the regions with a growing shortage of these resources (Korytnyi, 2015).

The analysis shows that Siberia is one of the water-saturated regions (after Brazil) of the world. Its average total river flow as per water content is $2350 \mathrm{~km}^{3}$ (55\% of a similar Russian value). It is important that $90 \%$ of the river flow in Siberia or $55 \%$ of the total Russian flow is formed on its territory (local flow) whereas the rest (transit flow) comes from adjacent territories. On the territory of Siberia there are almost 1,5 million rivers with a total length of about 5 million kilometers, including the Yenisei, Lena, Ob', the largest lakes (the Lake Baikal (the volume of $\left.23,000 \mathrm{~km}^{3}\right)$, Taimyr $\left(13 \mathrm{~km}^{3}\right)$ and Chany $\left(4,3 \mathrm{~km}^{3}\right)$ ) and the smaller ones (the lakes of Piasino, Teletskoe, Lama, Agata, Gusinnoe, Ubinskoe, etc.). The inventory of water resources also includes Siberian water storage reservoirs of the Angara-Yenisei basin, which are the largest in the country, and about 3 thousand glaciers of the Arctic islands and mountains, marshy ponds and groundwater horizons (Korytnyi, 2015).

Taking into account the availability of resources - more than 5 million hectares of arable land which has not been used for over 20 years, almost the same territory area which has had little or no mineral fertilizers for many years, clean water availability, good ecological situation in most territories, absence of large cities creating ecological background, a sufficient level of sunny days and temperature conditions suitable for cultivation of many agricultural crops, Siberia is one of the most important resources of the 
planet to supply its rapidly growing population, including Southeast Asia, China, part of India, and other areas, with food resources on the basis of mutually beneficial trade cooperation.

What is peculiar for the food development in the region? Are there any real tendencies for its increase and breaking into world markets?

According to the data of the expertanalytical center of agricultural business (Doklad ekspertno-analiticheskogo tsentra..., 2016), agricultural production in the krai was constantly growing in actual prices in 2013-2016 (Table 1).

Real food production in natural values in all fields of economy serve to confirm these conclusions (Tables 2, 3).

Adjusted for inflation and rise in prices, it is possible to estimate the development of food stock production in the region as "a moderate growth against the background of uncertain demand and uncoordinated support system".

Analysis of demand for local products in the regional market shows that there has been a decrease in the consumption of food products since 2014 (Table 4).

In conditions when domestic market is hardly growing, development of inter-regional and export food trade in the region becomes strategically important. This should maintain and develop food production in the region. The fundamental question arises: why is the food market so slow in growing and becoming saturated with food from neighbouring regions. Lack of investments and minor government support as main explanations of slowdown do not give answers, the reason being a high level of support in the krai. To find the answers a group

Table 1. Agricultural production in the krai in actual prices in 2013-2016

\begin{tabular}{|c|c|}
\hline Year & Overall production, in billion rubles \\
\hline 2013 & 70,2 \\
\hline 2014 & 79,2 \\
\hline 2015 & 88,9 \\
\hline 2016 & 93,3 \\
\hline
\end{tabular}

Table 2. Gross yield of main crop products (thousand tons)

\begin{tabular}{|l|c|c|c|c|c|c|}
\hline & 2011 & 2012 & 2013 & 2014 & 2015 & 2016 \\
\hline $\begin{array}{l}\text { Cereals and pulse crops (weight after processing), } \\
\text { thousand tons }\end{array}$ & 2359,2 & 1786,8 & 2214,5 & 2208,2 & 2253,9 & 2351,8 \\
\hline Potatoes, thousand tons & 1230,4 & 1124,1 & 1084,5 & 1155,5 & 1150,8 & 1240,5 \\
\hline Field vegetables, thousand tons & 262,3 & 248,3 & 228,6 & 217,2 & 225,0 & 235,6 \\
\hline Corn for food, thousand tons & 249,0 & 207,7 & 266,9 & 252,8 & 327,1 & \\
\hline
\end{tabular}

Table 3. Production of main livestock products (in economies of all categories), thousand tons

\begin{tabular}{|l|c|c|c|c|c|c|}
\hline & 2011 & 2012 & 2013 & 2014 & 2015 & 2016 \\
\hline $\begin{array}{l}\text { Cattle and poultry for slaughter (in slaughter weight), } \\
\text { thousand tons }\end{array}$ & 142,4 & 150,5 & 147,7 & 128,7 & 124,9 & 139,6 \\
\hline Milk, thousand tons & 723,7 & 726,9 & 708,1 & 724,5 & 739,8 & 732,6 \\
\hline Eggs, mln & 784,7 & 858,6 & 838,3 & 790,8 & 814,0 & 794,3 \\
\hline
\end{tabular}


of scientists from the Institute of Economics and Trade of the Siberian Federal University has been doing the research on the emerging cooperative network relationships in the food market of the region. Its relevance is determined by the fact that, according to experts and our observations, regional producers are less competitive compared to the producers from Siberian and Central Russian regions whose products displace the regional ones from the market.

The research is focused on four groups of the megaregions of the krai which have opportunities for cooperation and similar natural conditions. These megaregions are the Eastern one with its centre in the city of Kansk, the Western one with its centre in the cities of Achinsk and Nazarovo, the Southern one with its center in Minusinsk and the Central one with its centre in Krasnoyarsk (Materialy issledovaniia V.V. Kuimova, E.V. Shcherbenko, 2017). Some summary data resulting from this research are shown in Table 5.

This analysis shows that there are more than 11 thousand different enterprises of the food market (including 2369 producing and 407 processing ones, as well as 8783 enterprises selling food). It is undoubtedly a positive factor as this market concentrates labor and intellectual resources, which leads to the prospects for further development.

Yet, the researches, focusing on how concordantly these resources interact within the framework of modern cooperative-network

Table 4. Food retail turnover, including beverages, tobacco and non-food products (Doklad No. 1.37.1, 2016...)

\begin{tabular}{|c|c|c|}
\hline \multirow{2}{*}{ Year } & \multicolumn{2}{|c|}{ Food products, including beverages and tobacco products } \\
\cline { 2 - 3 } & \multirow{2}{*}{ Million rubles } & in $\%$ \\
\cline { 3 - 3 } & & as per corresponding period of the previous year \\
\hline $\mathbf{2 0 1 4}$ & $\mathbf{2 8 8 3 4 3 , 7}$ & $\mathbf{8 6 , 9}$ \\
\hline $\mathbf{2 0 1 5}$ & $\mathbf{2 1 3 5 7 5 , 6}$ & $\mathbf{9 9 , 0}$ \\
\hline $\mathbf{2 0 1 6}$ & $\mathbf{2 2 5 6 5 3 , 0}$ & \\
\hline
\end{tabular}

Calculation is based on the data 1. SOCIO-ECONOMIC SITUATION IN KRASNOYARSK KRAI IN 2016, REPORT No. 1.37.1

Table 5. Types of enterprises of the region's food market (regarding the megaregions) (Materialy issledovaniia V.V. Kuimova, E.V. Shcherbenko, 2017)

\begin{tabular}{|c|c|c|c|c|c|c|}
\hline \multirow[b]{2}{*}{ Megaregion } & \multicolumn{5}{|c|}{ Types of enterprises, operating in the food market } & \multirow[b]{2}{*}{ Total } \\
\hline & \begin{tabular}{|c|} 
Producing \\
agricultural \\
products
\end{tabular} & \begin{tabular}{|c|} 
Processing \\
agricultural \\
products
\end{tabular} & Catering & $\begin{array}{c}\text { Wholesale } \\
\text { trade }\end{array}$ & $\begin{array}{l}\text { Retail } \\
\text { trade }\end{array}$ & \\
\hline Eastern & 582 & 67 & 61 & 51 & 903 & 1664 \\
\hline Western & 468 & 20 & 123 & 75 & 303 & 990 \\
\hline Southern & 596 & 94 & 104 & 60 & 784 & 1638 \\
\hline Central & 401 & 67 & 109 & 119 & 688 & 1384 \\
\hline Northern & 32 & 17 & 33 & 51 & 279 & 412 \\
\hline Total: regions of the krai & 2079 & 265 & 430 & 356 & 2957 & 6087 \\
\hline Cities of the krai & 290 & 142 & 898 & 2195 & 1947 & 5472 \\
\hline Total: enterprises of the food complex & 2369 & 407 & 1328 & 2551 & 4904 & 11559 \\
\hline
\end{tabular}


Table 6. Cooperative-network relations in the food market of Krasnoyarsk Krai (in a light of megaregions) (Materialy issledovaniia V.V. Kuimova, E.V. Shcherbenko, 2017)

\begin{tabular}{|l|c|c|c|c|c|}
\hline \multirow{2}{*}{ Megaregion } & \multicolumn{5}{|c|}{$\begin{array}{c}\text { Number of enterprises that have started network relationships } \\
\text { (network-based enterprises) }\end{array}$} \\
\cline { 2 - 6 } & $\begin{array}{c}\text { Enterprises } \\
\text { producing } \\
\text { agricultural } \\
\text { products }\end{array}$ & $\begin{array}{c}\text { Enterprises } \\
\text { processing } \\
\text { agricultural } \\
\text { products }\end{array}$ & $\begin{array}{c}\text { Public catering } \\
\text { establishment }\end{array}$ & $\begin{array}{c}\text { Wholesale } \\
\text { distributor }\end{array}$ & $\begin{array}{c}\text { Retail trade } \\
\text { enterprise }\end{array}$ \\
\hline Eastern & 106 & 8 & 11 & 9 & 234 \\
\hline Western & 34 & 11 & 13 & 7 & 54 \\
\hline Southern & 104 & 12 & 9 & 11 & 102 \\
\hline Central and northern & 84 & 6 & 7 & 19 & 212 \\
\hline Cities of the krai & 43 & 14 & 43 & 214 & 56 \\
\hline $\begin{array}{l}\text { Total: enterprises of the food } \\
\text { complex }\end{array}$ & $371 / 16 \%$ & $51 / 13 \%$ & $83 / 6 \%$ & $260 / 10 \%$ & $658 / 13 \%$ \\
\hline
\end{tabular}

formats to achieve new results, show that the situation is far from being optimistic. We analyzed the elements of the primary network interactions, regarding these interactions to be the basis for modern relationships and mutual competitiveness growth (Table 6).

Therefore, these data characterize food complex of the krai as a fairly fragmented group of companies with uncoordinated ultimate goals and poor results.

According to our research, the general trends of the food market of Russia and the region do not fit in with modern trends, including the processes of "network revolution", to which, in the opinion of some foreign and Russian scientists (N.V. Smorodinskaia, M.Iu. Sheresheva, A.N. Asaul, V.V. Kuimov), qualitatively new synergies through the integration of certain resources, access to consolidated resources, formation of a unified information and marketing field, competitors' cooperation, etc. are inherent. This increases stability on the market and ensures achievement of competitive advantages by each participant of these processes (Mirovoe budushchee..., 2017; Preobrazovanie nashego mira..., 2015; Global'nye tendentsii - 2030..., 2012).
So, there is a significant lag from modern network interactions on the region's food market, and it is a factor limiting its competitiveness and qualitative growth.

What structures could be integrators of the region's food market development on a new cooperative-network basis? The practice shows that they are consumers, processing enterprises and intermediary structures that provide the delivery of goods from producer to consumer.

The following groups of integrators can be distinguished for the region:

- local consumers (stalls, pavilions, shops, public catering enterprises, small purchasing enterprises and own marketing network of manufacturers in the village area);

- local processing enterprises that use the regional producers' products (meat, milk, eggs, grain, fish, water, etc.);

- regional and federal networks purchasing products from local producers and providing its processing and sales;

- logistic structures of a wholesale chain, including METRO, O'KEY, etc.;

- public catering networks with their own procurement structure; 
- state and municipal purchases using regional products for their contract performance security;

- organizations providing export of locally produced food in other regions and abroad.

The summary data regarding the integrators' role in fostering the food production development in the region are presented in Table 7.

The data in Table 7 summarize the author's 7-year research results regarding these integrators' role in fostering the food production development in the region. They show that:

- there are very complex multidirectional processes which do not give a necessary impulse for the development;

- all structures under consideration can be a driving force for the food market subjects entering a new phase of development through cooperationnetwork interaction, but these are processing enterprises, regional and federal trading networks, the system of public and municipal procurement that have the most powerful influence, provided that they are focused on the use of regional manufacturers' products;

- business networks (including producing and processing enterprises and logistics) and retail, aimed at the satisfaction of the population's need in food products for the account of local and regional production, play the most powerful role of modern development integrators.

The research has shown that several major companies start their slow transition to new forms of interaction and strategic cooperation with local manufacturers. These are, first of all, different formats of cooperative-network interaction which are widespread in the world. These companies are the following ones in the region:

- "Saianmoloko Ltd." which organized cooperation with milk producers in many areas of the krai and Khakassia, where the company bought a share of ownership, became a member of the management board and has been developing milk production. In other cases it concludes contracts with small producers, subsidizes the purchase for them (procurement of fodder, veterinary services and milking). All this creates the prospect for the development;

- "Minusinsk Milk Ltd." has also been focusing on a long term perspective. Basically it concludes contracts with farms, supporting them in procurement of fodder, timely payment for milk supply. This also creates a good basis for the development of small and home milk production. It is here where "Poleznye produkty" ("Healthy products") production-and-marketing cooperative was established. Several enterprises producing dairy products and a large logistic center cooperating with it became its members on the network cooperation basis. Retaining their legal and economic autonomy, these enterprises have united their forces in marketing their products. Having their joined yearly resource of dairy products for more than a billion rubles and being able to guarantee the regularity of dairy products supplies to trade networks, they have become desirable partners for a large regional trade network;

_ “Kraipotrebsoiuz" has been establishing fairly logical perspective activity. It is primarily characterized by a wide scope of activities production, processing, growing and processing of wild-growing plants (berries, mushrooms, fern, nuts) which are purchased by the population of remote settlements and thus secure the economic basis of their life. The company has developed deep processing (production of sausages, different types of meat, dairy products, fruit drinks, juices, pickles, preserves, baked goods), growing and selling of wild-growing plants. The company has been actively developing export direction. With the annual production volume of more than a billion rubles the company has been successfully expanding its production, domestic and export markets. 


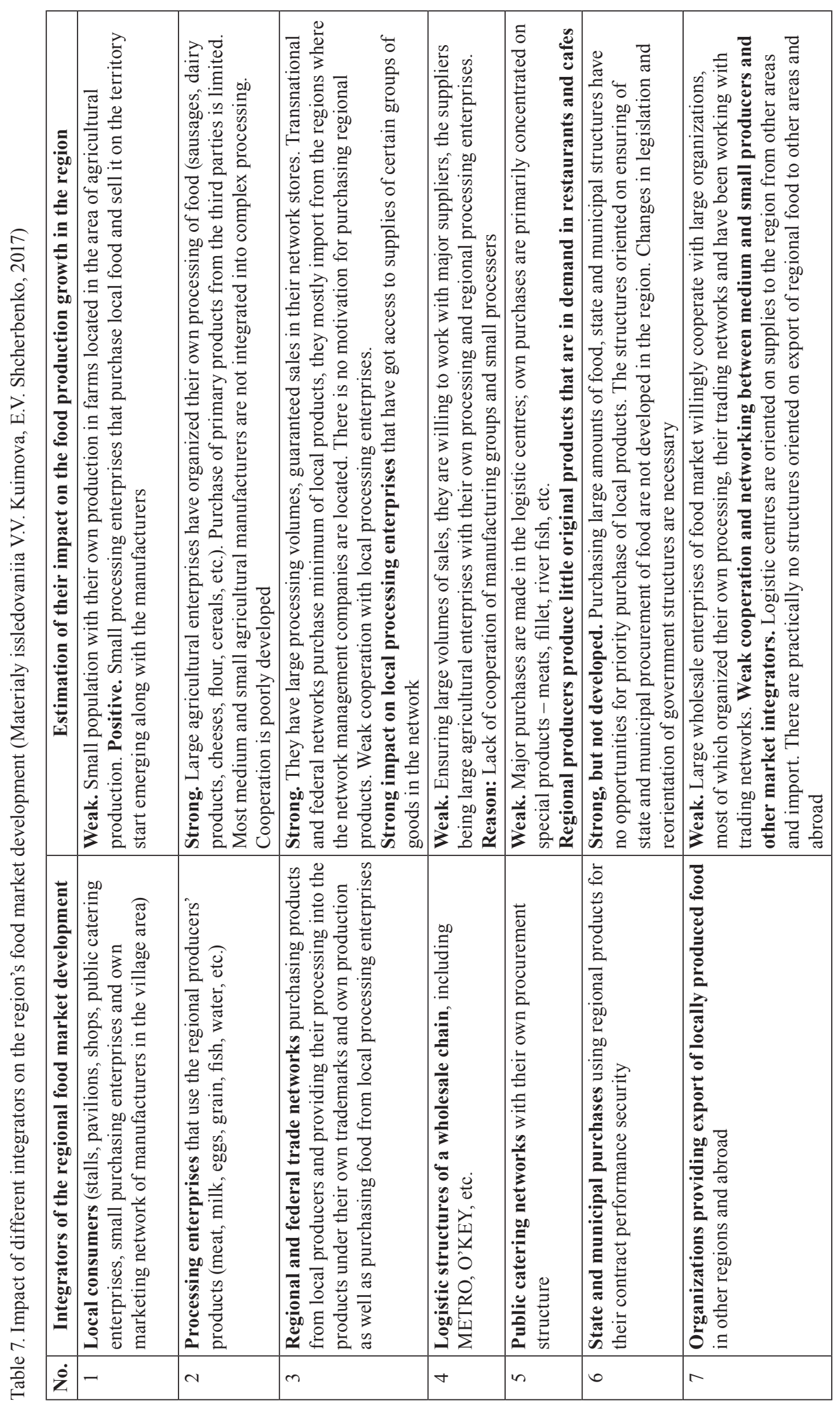




\section{Conclusion/Results}

Food market in the region potentially has significant resources for the increase of food production and its export. Realization of the opportunities is considerably limited by the lag in cooperation and development of network interactions between enterprises of the market.
The process of transformation of the economy of this complex to modern patterns of work is in slow progress. Considerable efforts of entrepreneurs and regional authorities are required to accelerate this process as the basis of competitiveness and promotion of goods the the interregional and international markets.

\section{References}

Doklad ekspertno-analiticheskogo tsentra agrobiznesa. Sel'skoe hoziaistvo Krasnoiarskogo kraia [Report of the Expert and Analytical Centre of Agricultural Business. Agriculture of Krasnoyarsk Krai] (2016). Available at: http://ab-centre.ru/page/selskoe-hozyaystvo красноярского края (accessed 10 April 2017).

Doklad No. 1.37.1, 2016. Sotsial'no-ekonomicheskoe polozhenie Krasnoiarskogo kraia [Report No. 1.37.1, 2016. Socio-Economic Situation in Krasnoyarsk Krai].

Global'nyetendentsii-2030: Obzor. Megatendentsii [Global Trends 2030: Overview. Megatrends] (2012). Available at: http://eurasian-defence.ru/sites/default/files/DS/Documents/global-trends-2030rus.pdf (accessed 10 April 2017).

Korytnyi, L. (2014). Vodnye resursy Sibiri v nastoiashchem i budushchem [Water Resources of Siberia in the Present and Future]. Available at: http://www.fesmos.ru (accessed 10 April 2017).

Kuimov, V.V., Suslova, Iu.Iu, Shcherbenko, E.V, Pankova, L.V (2015). Marketingovye tekhnologii v razvitii rynkov prodovol'stvennykh tovarov regionov Sibiri [Marketing Techniques in the Development of Food Markets of Siberian Regions]. Krasnoyarsk, SFU, 268 p.

Mirovoe budushchee prodovolstvennoi bezopasnosti pod voprosom, FAO [The World's Future Food Security is Open to Question] (2017). Available at: http://avesta.tj/2017/02/23/mirovoe-budushheeprodovolstvennoj-bezopasnosti-pod-voprosom-fao/ (accessed 5 April 2017).

Materialy issledovaniia V.V. Kuimova, E.V. Shcherbenko [Research Materials by V. Kuimov, E. Shcherbenko] (2017). Krasnoyarsk.

Preobrazovanie nashego mira: Povestka dnia v oblasti ustoichivogo razvitiia na period do 2030 goda [Transformation of Our World: Agenda for Sustainable Development till 2030] (2015). Available at: http:/unctad.org/meetings/en/SessionalDocuments/ares70d1_ru.pdf (accessed 10 April 2017). 


\title{
Продовольственные ресурсы Сибири и региона \\ и перспективы устойчивой работы \\ на глобальных рынках
}

\author{
В.В. Куимов, Е.В. Щербенко \\ Сибирский федеральный университет \\ Россия, 660041, Красноярск, пр. Свободный, 79
}

\begin{abstract}
$\overline{\text { Приводится анализ ресурсов Сибири и региона по производству продовольствия для реализа- }}$ ичи Повестки дня ООН в области устойчивого развития на период до 2030 г. Показываются существенные преимущества Сибири на фоне значительных изменений климата в других, в том числе густонаселенных, территориях земли и особенно нарастающего недостатка воды и водных ресурсов как основы производства продовольственных ресурсов в этих территориях. Несмотря на новые технологии и экономное потребление воды, значение территорий земли с высокой обеспеченностью водой и климатическими условиями для развития продовольствия, в том числе Сибири, Новой Зеландии, отдельных территорий тропической зон, приобретает стратегическое значение для человечества. Показаны значительные неиспользуемые ресурсы сибирских регионов и Красноярского края в том числе, где не используются более 5000 млн га ранее пахотных земель, ресурсы для животноводства и дикоросы, имеются значительные возможности для формирования современных кооперачионно-сетевых взаимодействий для быстрого роста продовольственного рынка и экспорта на глобальные рынки.
\end{abstract}

Ключевые слова: устойчивое развитие, продовольствие, Сибирь, ресурсы для продовольствия, экспорт.

Научная специальность: 08.00.00 - экономические науки. 